\title{
農作物生産用温室におけるバイオマス燃焼の適用課題
}

\section{Application Problem of Biomass Combustion in Greenhouses for Crop Production}

\author{
川村淳 浩*・秋 澤 淳**・柏木孝夫** \\ Atsuhiro KAWAMURA, Atsushi AKISAWA and Takao KASHIWAGI
}

(Received November 6, 2006)

\begin{abstract}
It is consumed much energy in fossil fuels to production crops in greenhouses in Japan. And flue gas as $\mathrm{CO}_{2}$ fertilization is used for growing crops in modern greenhouses. If biomass as renewable energy can use for production vegetables in greenhouses, more than $800,000 \mathrm{kl}$ of energy a year (in crude oil equivalent) will be saved.

In this study, at first, we made the biomass combustion equipment, and performed fundamental examination for various pellet fuel. We performed the examination that considered an application to a real greenhouse next. We considered biomass as both a source of energy and $\mathrm{CO}_{2}$ gas for greenhouses, and the following findings were obtained:

1) Based on the standard of $\mathrm{CO}_{2}$ gas fertilization to greenhouses, it is difficult to apply biomass as a $\mathrm{CO}_{2}$ fertilizer, so that biomass should be applied to energy use only, at least for the time being.

2) Practical biomass energy machinery for economy, high reliability and greenhouses satisfying the conservatism that it is easy is necessary.

3) It is necessary to develop crop varieties and cultivation systems requiring less strict environmental control.

4) Disposal of combustion ash occurring abundantly, effective practical use is necessary.
\end{abstract}

Key Words: Woody Biomass, Combustion, Greenhouses for Crop Production, $\mathrm{CO}_{2}$ Fertilization, Ash

\section{1. 研究背景と目的}

我が国におけるビニールハウスやガラス温室等の作物生 産用施設（以下，温室）の設置面積は $5 \times 10^{8} \mathrm{~m}^{2}(5$ 万 ha） におよび，そのうち $40 \%$ 余りの温室で暖房（以下，加温） がおこなわれている。その多くが化石燃料によるものであ り，温室野菜生産では原油換算で年間 80 万 $\mathrm{k} \ell$ 余のエネ ルギーが投入されている。園芸農業と呼ばれるこの農法は エネルギー多消費型農業の典型と目されているが，我々の 健康バランスを保つために欠かせない安全安心な国産生鮮 食品を生産しているため, 従来から省エネルギーへの取り 組みがなされ，代替エネルギーの適用も繰り返し検討され てきた ${ }^{1)}$ 。現在では，作物の作型毎に温度管理を中心とし た標準的な栽培管理技術が定められ，安定生産を支えてい る2)。

温室内の作物は，閉鎖空間で光合成がおこなわれるため に二酸化炭素の極端な不足状態に陥る場合がある。特に, 大気の数倍程度の高二酸化炭素ガス濃度環境で栽培生産す ることにより収量が大きく増える作物がある。このため,
作物の生育補償や生育促進のために二酸化炭素ガスを肥料 として供給（以下，施肥）する栽培技術が存在し，近代的 な園芸農業では欠くことができない。このような技術は, 我が国のように限られた土地で良質の作物を効果的に生産 するために不可欠なものとなっている。二酸化炭素ガス源 としては，石油系燃料を使用する加温用燃焼熱源（以下， 化石燃料加温機）や専用発生機からの燃焼排ガスを利用す る方式（以下，燃焼式）が，液化二酸化炭素を充填容器か ら気化放出する方式（以下，気化式）よりも経済性に優れ ているために広く普及している。しかし，最近ではエネル ギー・環境的側面を考慮することも求められている3)。

このような園芸農業に対して再生可能エネルギー・資源 であるバイオマスを適用しようとする取り組みは全国各地 の地方自治体が作成するバイオマスタウン構想等にしばし ば見かけ，木質バイオマス利活用プロジェクトが多くを占 めている ${ }^{4)}$ 。木質バイオマス資源のエネルギー利用につい ては, 燃焼利用（直接燃焼，混焼，固形燃料化等）と熱化 学的変換 (ガス化, 液化, 炭化等), そして生物化学的変換 (主

*ネポン株式会社 技術本部（７243-0215＼cjkstart神奈川県厚木市上古沢 411）

NEPON Inc. (411 Kamifurusawa, Atsugi, Kanagawa 243-0215, Japan)

* * 東京農工大学大学院（

Tokyo University of Agriculture and Technology (2-24-16 Nakacho, Koganei, Tokyo, 184-8588, Japan) 
にエタノール醗酵）に分類されている5)。これらの園芸農 業への適用を選択する場合, 小規模分散型, サプライイン フラ, そして実用化度合という観点から, 燃焼利用が有望 視されている。ところが, 実用段階に到達しているはずの 燃焼利用にも園芸農業適用に関しては実は多くの解決すべ き問題が今なお存在し, 経済性とあいまって普及を阻む要 因となっている。そのため, 現在までの我が国における実 施例は数例に留まり, 適用の進展は思わしくない。

これまで筆者らは, 園芸農業の省エネルギーを推進する ために, 実在する温室のエネルギー・二酸化炭素ガス消費 実測に基づいたコージェネレーションシステム適用を検討 してきた ${ }^{6)}$.7)。また, 燃焼式二酸化炭素ガス施肥に欠かせ ない清浄度基準の策定も試みてきた ${ }^{8)}$ 。

これらの知見を基に本研究では, 温室に対するエネル ギー供給・二酸化炭素ガス施肥源として木質バイオマスの 燃焼利用を対象とした技術的適用検討をおこない, 我々の 健康を支える重要な使命の一方で大量の化石エネルギーを 消費する園芸農業にバイオマスエネルギーを適用する場合 の課題を抽出し, 適用拡大に向けた一助とすることを目的 とした。

\section{2. 木質バイオマスの直接燃焼の検討}

我が国の平均的な温室は, 1 棟 $500 \mathrm{~m}^{2}$ 程度のビニールハ ウスで，A 重油を燃料とする定格熱出力 $116 \mathrm{~kW}$ 級の温風 式化石然料加温機が設置されている。木質バイオマスを直 接燃焼で温室に適用するために, ペレット燃料化した木質 バイオマス（以下，ペレット）の直接燃焼の特徵について 実験的検討をおこなった。

\section{1 燃焼試験装置}

Fig. 1 に, ペレットを燃焼炉内部で燃焼し, 燃焼ガスを 熱交換器, サイクロン集塵機, そして誘引送風機を経て煙 突から系外に排出する燃焼試験装置（定格熱出力 $116 \mathrm{~kW}$ ) の構成を示した。ペレットを直接燃焼する定格熱出力 116 $\mathrm{kW}$ 級の熱利用機器として市販されている多くの製品に共 通する構成とした。燃焼炉は固定火格子で上下空間に仕切 る構造とした。上空間は, 側面にペレット落下供給口と点 火用灯油バーナ, 天面に燃焼ガスの流出口を配置し, 内面 全体を耐火材で覆って燃焼室とした。下空間は, 側面に配 置した押込送風機によって燃焼空気を導入し（空気室とし ての機能), 同時に燃焼灰を溜める灰回収室としての機能を 持たせた。すなわち, 広い面積を有する火格子の任意の場 所において，火格子の下方から上方に燃焼空気，上方から 下方に燃焼灰が通過する。火格子は金網製もしくは耐火七 ラミックス製とした。灯油バーナの定格燃焼量は燃焼試験 装置熱出力の半分程度とし, 灯油消費量は作動時間で調節 した。

燃焼試験装置の運転は，プログラマブルシーケンサに

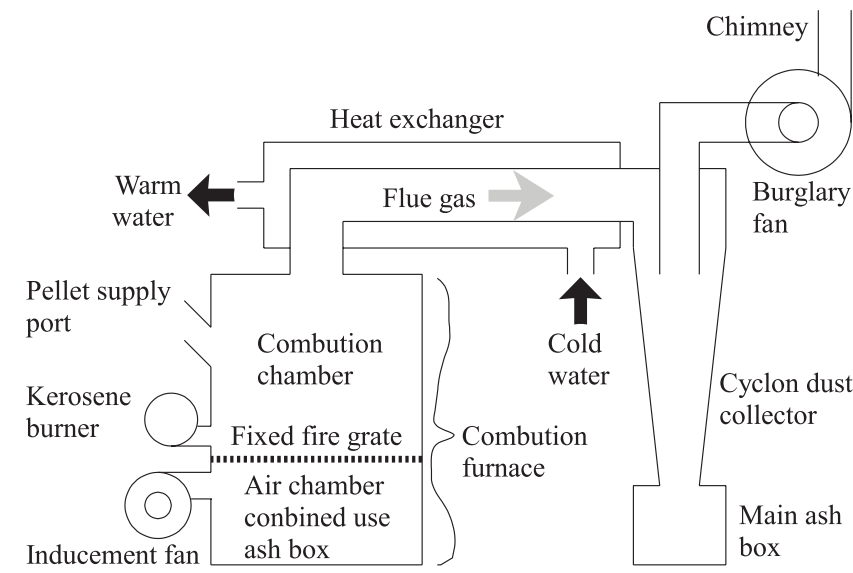

Fig. 1 Schematic diagram of biomass combustion examination equipment.

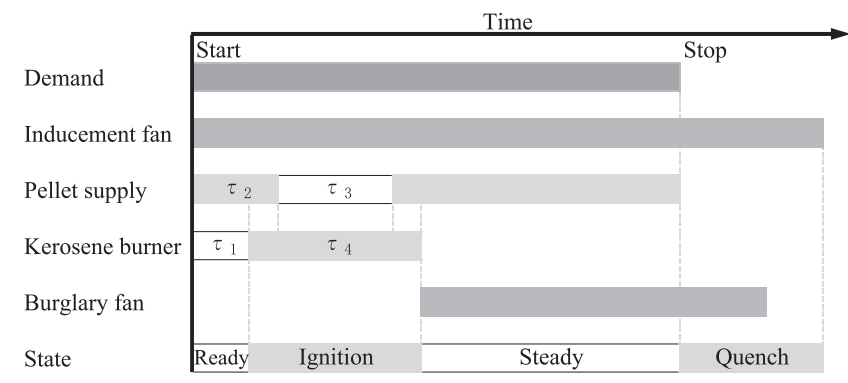

Fig. 2 Timing chart of biomass combustion examination.

よって各機器の作動開始タイミングや作動時間を任意に調 整することでおこなった。基本シーケンスを Fig. 2 に示し た。運転開始と共に火格子上へのペレット供給を始め，任 意時間経過後 $\left(\tau_{1}\right)$ 点火用灯油バーナを作動させた。ペレッ 卜供給は，火格子上のペレットに早く火が回るように，供 給開始から任意時間経過後 $\left(\tau_{2}\right)$ に一旦停止 $\left(\tau_{3}\right) し て$ 再投入した。灯油バーナは, ペレットでの自燃が確保でき るまで $\left(\tau_{4}\right)$ 作動させた。この間, 誘引送風機と押込送風 機の運転バランスによって燃焼室内圧力を常時負圧に保っ た。

一方運転停止は, ペレット供給を停止して火格子上のペ レットを自然により燃え尽きさせることでおこなった。

\section{2 供試ペレット}

Table 1 に, 3 種類の供試ペレットの性状を示した。ホワ イトペレットは北欧産の木部, 混合材ペレットとバークペ レットは国内産の木部と樹皮を原料として国内で製造販売 されているものである。水分, 灰分, 揮発分, 窒素分の違 いが顕著である。

\section{3 試験条件と方法}

それぞれの供試ペレットについて, 少ない灯油消費量で の確実点火し (以下, 最適点火条件), ペレット燃焼が低空 
Table 1 Test sample properties of wood pellets.

\begin{tabular}{|ll|r|r|r|}
\hline & & White & Mixed & \multicolumn{1}{c|}{ Bark } \\
\hline Moisture & {$[\mathrm{wt} \%]$} & 7.47 & 10.62 & 11.18 \\
\hline Ash & {$[\mathrm{wt} \%]$} & 0.28 & 0.88 & 3.90 \\
\hline Volatile & {$[\mathrm{wt} \%]$} & 85.10 & 81.78 & 70.85 \\
\hline Carbon & {$[\mathrm{wt} \%]$} & 50.06 & 50.34 & 49.71 \\
\hline Hydrogen & {$[\mathrm{wt} \%]$} & 6.39 & 6.54 & 6.15 \\
\hline Nitrogen & {$[\mathrm{wt} \%]$} & $<0.10$ & 0.15 & 0.44 \\
\hline Sulfur & {$[\mathrm{wt} \%]$} & $<0.02$ & $<0.02$ & 0.04 \\
\hline HHV & {$\left[\mathrm{MJ} \mathrm{kg}^{-1}\right]$} & 20.56 & 21.14 & 20.22 \\
\hline LHV & {$\left[\mathrm{MJ} \mathrm{kg}^{-1}\right]$} & 18.93 & 19.40 & 18.55 \\
\hline
\end{tabular}

Table 2 Optimum conditions of experiment.

\begin{tabular}{|ll|r|r|r|}
\hline & & White & Mixed & \multicolumn{1}{|c|}{ Bark } \\
\hline Input & {$[\mathrm{kW}]$} & 136 & 136 & 135 \\
\hline Output & {$[\mathrm{kW}]$} & 115 & 116 & 115 \\
\hline$\tau_{1}$ & {$[\mathrm{sec}]$} & 30 & 30 & 30 \\
\hline$\tau_{2}$ & {$[\mathrm{sec}]$} & 45 & 45 & 45 \\
\hline$\tau_{3}$ & {$[\mathrm{sec}]$} & 60 & 60 & 90 \\
\hline$\tau_{4}$ & {$[\mathrm{sec}]$} & 180 & 180 & 240 \\
\hline \multicolumn{2}{|l|}{ Excess air ratio $[-]$} & 1.9 & 1.9 & 2.3 \\
\hline
\end{tabular}

気過剩率でおこなわれかつ火格子上の燃焼残椬が少なくな る条件（以下，最適燃焼条件）を探った。

\section{4 結果と考察}

Table 2 に，各供試ペレットの最適点火条件と最適燃焼 条件を示した。これらはホワイトペレットと混合材ペレッ トでは大差がないが, バークペレットでは確実に点火させ るために，灯油バーナ作動時間（ $\left.\tau_{4}\right)$ と先行投入ペレット の燃え広がり待ち時間 $\left(\tau_{3}\right)$ を多く必要とし, 定常運転時 も多くの燃焼空気を必要とした。バークペレットに点火し づらかった原因をT Table 1 から推察すると，バークペレッ トの揮発分がひときわ小さいことがあげられる。また，他 に影響が大きいと思われた水分量は混合材ペレットとバー クペレットで大差がなかったため，本条件の範囲では影響 が現れにくかったと推察した。

Fig. 3 に，点火から定常燃焼状態を経て消火に至るまで の一連の運転状況の例を排ガス温度推移で示した。また, 定格熱出力 $116 \mathrm{~kW}$ の化石燃料加温機の排ガス温度推移も 示した。点火用灯油バーナを作動させると排ガス温度が上 昇し始めるが, 発生熱量が小さいために化石燃料加温機よ りも立ち上がりが鈍い。その後, ペレットへの火移りが完 了し，ペレットだけで然焼し始め，しばらく排ガス温度が 上昇を続けた後に定常状態となった。結果的に，化石然料 加温機よりも排ガス温度上昇の遅れが見られた。これは, 同出力の化石燃料加温機よりも温室内の室温を設定温度ま で上げるために長い時間を要することを意味する。一方, 消火時は，火格子上にしばらくの間燃焼中のペレットが留 まっていたため, 排ガス温度の降下は化石燃料加温機より も鈍かった。ここで, $\tau_{\mathrm{sp}}$ と $\tau_{\mathrm{sf}}$ はペレットと $\mathrm{A}$ 重油の場合

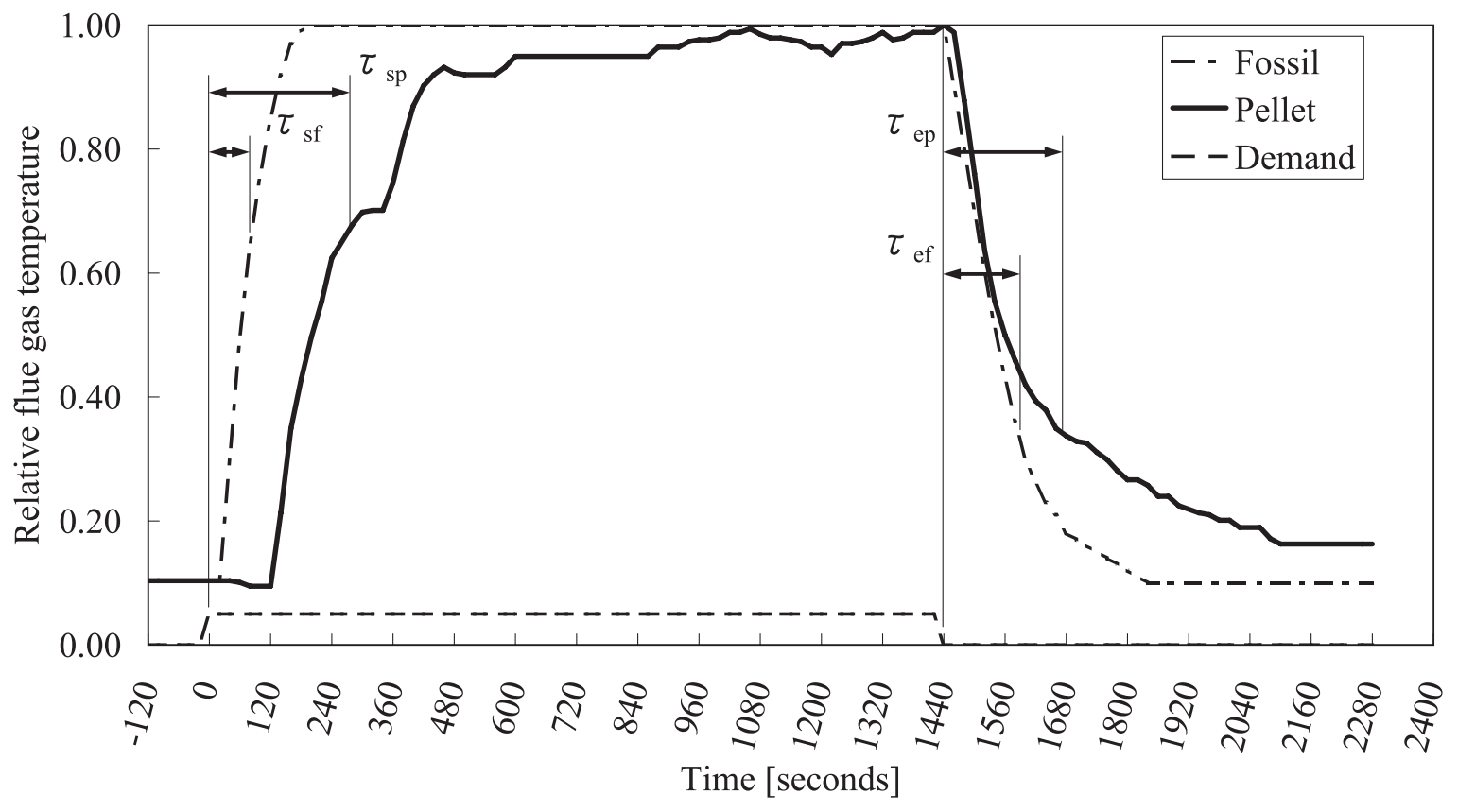

Fig. 3 Changes of flue gas temperature. 
の運転開始時の温度上昇遅れ時間， $\tau_{\mathrm{ep}}$ と $\tau_{\mathrm{ef}}$ はそれぞれの 運転停止時の温度降下遅れ時間を表す。起動時の温度上昇 が遅い理由は, 燃焼開始前にペレットを事前投入する必要 があるためでもあり，実用化に向けた改善のポイントであ ることが判った。

また，バークペレットを燃焼した場合，条件に関わらず 火格子上にクリンカーが生成した。生成例を Photo. 1 に 示した。硬く鈍い艶を放つガラス状の外観で, 燃焼空気や 燃焼灰が通過する火格子の溝や孔を塞ぐために安定な燃焼 の継続を阻害した。また，火格子が耐火セラミックス製の 場合, 固着して人為的に取り除くことが困難であり, 結果 的に火格子の損傷を招いた。クリンカーは特に利用価值が なく，産業廃棄物としての処理費用が峪む恐れがある。灰 分が多いペレットは, 燃料成分が全て燃焼しても灰だけで 空間的形状をほほ保っており, 充分に酸素が供給された状 態で高温にさらされ続けることで結晶化（すなわちクリン カーに変質) する 9), 10), 11), 12)。

すべての供試ペレットにおいて，点火時に煙突からの煙 の発生が見られた。バークペレットでは定常燃焼状態でも 比較的多くの煙が視認できた。簡易的にバッカラッカ・ス モーク・テスタを用いてろ紙に吸引してみると, 茶褐色状 に色づいた。更に，燃焼ガスの組成分析をおこなったとこ ろ, ペレットの種類に関係なく定常燃焼状態でも最大で数 百 ppmの一酸化炭素が検出された。木質バイオマス燃焼機 は，大気污染防止法によるばい煙発生施設に指定される場 合, 一定規模 (伝熱面積 $10 \mathrm{~m}^{2}$ ) 以上の施設について大気 污染に関する規制值の遵守を求められる。

\section{3. バイオマス燃焼装置の温室適用の検討}

\section{1 温度制御について}

前述の燃焼試験装置での結果より，制御性が著しく劣る ことが懸念された。そこで, 温室での使用を想定して実験 室の室温を一定に保つべく運転させる検討をおこなった。

3.1 .1 検討対象と条件

Fig. 4 に，この検討に用いた実験対象を示した。これは, $\mathrm{N}$ 社敷地内の開発試験棟一角の容積約 $1,000 \mathrm{~m}^{3}$ の実験室に 前述の燃焼試験装置を温風式に改造して設置したもので, 室温をサーモスタット（制御幅：設定温度の $\pm 10 \%$ 程度） で一定温度に保つようにオン・オフ運転させた。前述のホ ワイトペレットを使用し，燃焼入力を $136 \mathrm{~kW}$ とし。た だし，熱交換器を使用せずに燃焼炉からの熱回収だけとし たため, 温風出力は $58 \mathrm{~kW}$ 程度であった。

3.1 .2 結果と考察

Fig. 5 に室温制御結果の一例を示した。これより, 設定 温度に対して $\pm 15 \%$ 程度変動し, オーバーシュート時間は 15 分程度, そしてアンダーシュート時間は 5 分程度であっ た。これらの関係は, 暖房負荷と加温能力の関係も大きな 影響因子であるが，本試験装置のように起動と停止に多く

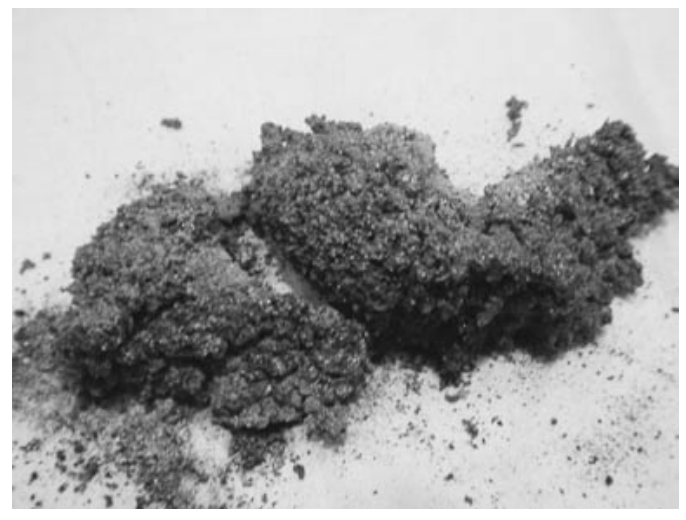

Photo 1 Generation example of clinker.

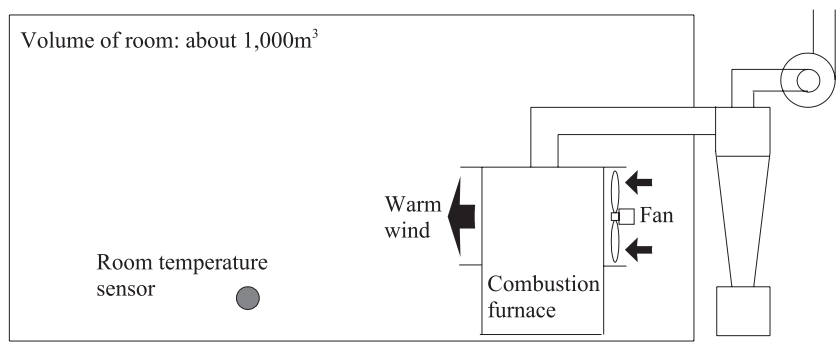

Fig. 4 Schematic diagram for temperature control characteristic.

の時間を必要とするために制御幅を広く取らざるを得ない 熱源では，オーバーシュートとアンダーシュートが大きく 出る。温室の暖房負荷は加温期間を通じて一定ではなく, 秋口と春先は暖房負荷が軽すぎるために，この状態では 制御性が悪くて室温の乱高下を招く恐れがあることが判っ た。

我が国の温室は簡単構造で比較的小面積のビニールハウ スが多くを占め, 化石燃料加温機が設置されている。また, 少数であるが, 理想的な栽培管理を追求する場合には温湯 式加温とする場合がある。温湯式加温は, 温室との間を循 環する温湯に加温機内に貯えた高温湯を差し湯しながら調 節する方式で，非常に正確で㮹密な室温制御が実現できる。

例えばメロンの場合, 温度管理基準によって最高温度と 最低温度が $1 \sim 2{ }^{\circ} \mathrm{C}$ 単位で決められており, 厳格な温度管 理が求められている。もちろん作物の一生のうちに数回こ の範囲を少しだけ逸脱してはならないというほどではない が, 毎日のようにいつも低温に曝されたり，極端な温度環 境にしばらく曝されたりすると，生育障害，収量低下，あ るいは品質劣化に見舞われてしまう。温室での作物生産は, 1 年のうちで秋口から厳冬期を経て春先までの期間におこ なわれるのが一般的で，この間暖房負荷が大きく変動する。 加温機の定格熱出力は, その地域の厳寒期の最低温度, 温 室保温性能, そしてその時期の栽培管理温度から最大暖房 負荷を算出して選定される ${ }^{13)} 。$ 一方，秋口と春先は暖房負 


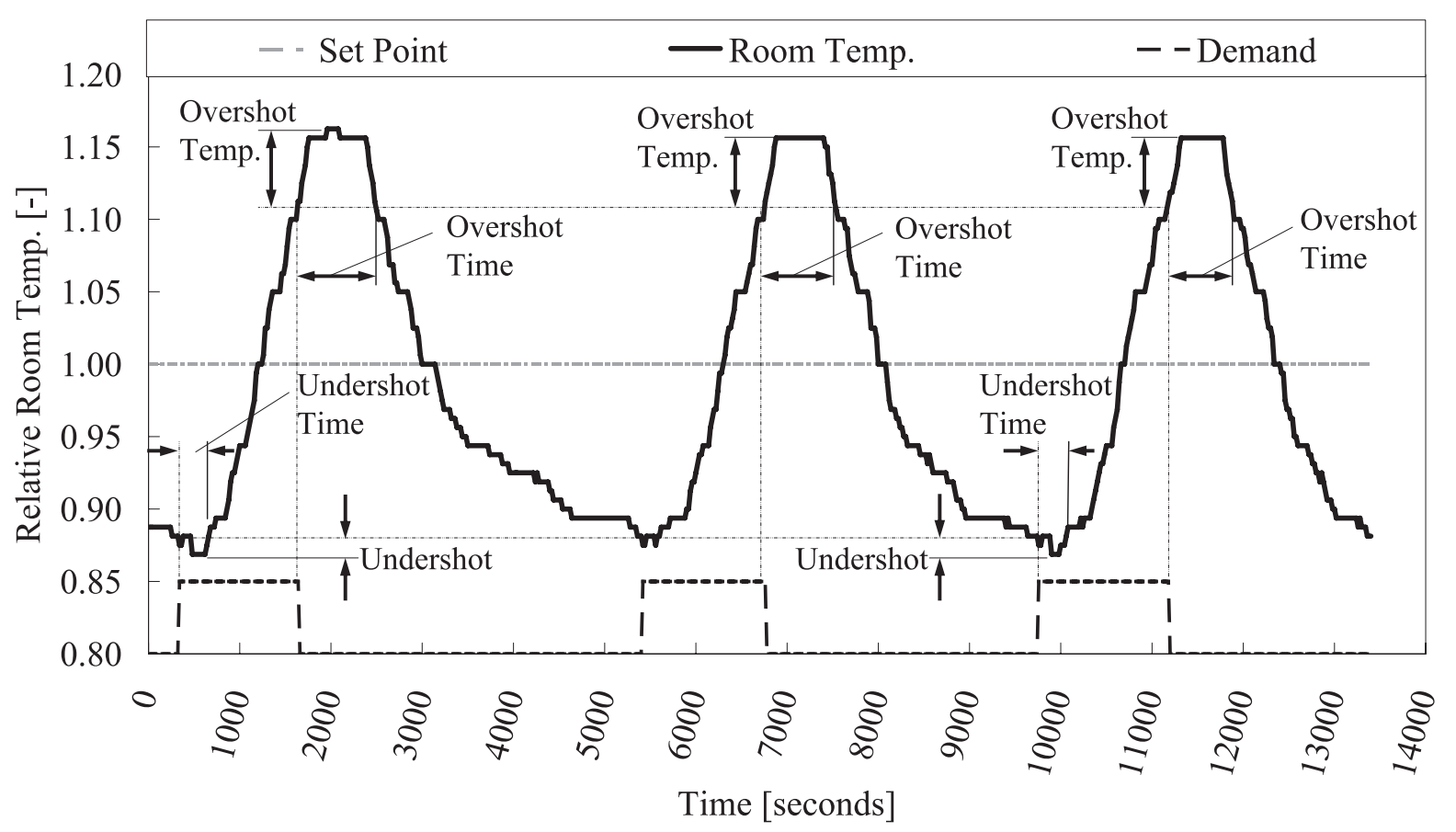

Fig. 5 Example Chart of Biomass Combustion Examination.

荷が軽いため，比較的小さな熱出力の加温能力で間に合う。 しかし, 経済性, 高信頼性, そして保守容易性が要求され る温室加温機は，オン・オフ制御方式が選択されており, 出力制御は運転時間でおこなわれる。すなわち, 暖房負荷 の軽い季節は高い周波数応答性を活かして頻繁な発停を繰 り返すことで，軽負荷への対応を行っている。

しかし, 同様な運転特性を木質バイオマス燃焼機に求め るのは困難である。栽培管理基準は空気伝染性病害の発生 予防 ${ }^{14)}$ や作型での安定生産の前提であるが, 現行の栽培管 理基準や作型には適合しない恐れがあることが判った。

実用に際しては, 点火・消火性を化石燃料加温機並みに 近づけ, 経済的, 高信頼性, かつ保守容易性を備える夕一 ンダウン機能を有する機器を開発する必要があるが, 緩や かな温度管理でも安定生産が可能な作型の作物への改良も 必要と思われる。

したがって，現在の市販機器で，すぐに温室に適用する 場合, 温湯式バイオマス燃焼機と輻射放熱器や温風放熱器 による組み合わせが最も現実的と思われる。

\section{2 排ガス清浄度について}

近代的な園芸農業への適用を想定し, 木質バイオマス燃 焼機の排ガスを温室への二酸化炭素ガス施肥に適用する場 合の課題を検討した。

\subsection{1 検討対象の設定（モデル化）}

Fig. 6 に, 温室への二酸化炭素ガス施肥を想定した模式 眓を示した。二酸化炭素ガスの供給方式に主眼を置いて, (a) は室内発生方式, (b) は送風ダクト方式と称される。前者は

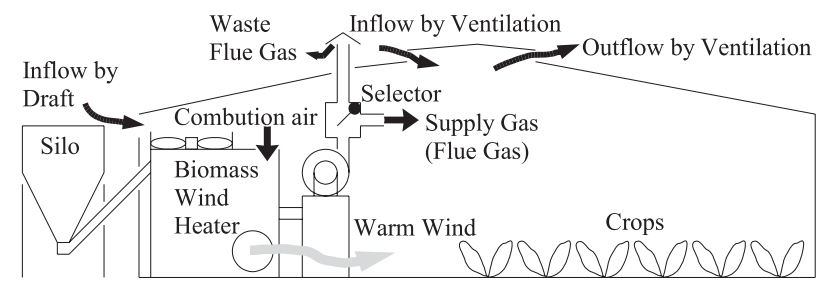

(a) Flow model of Indoor Generation System

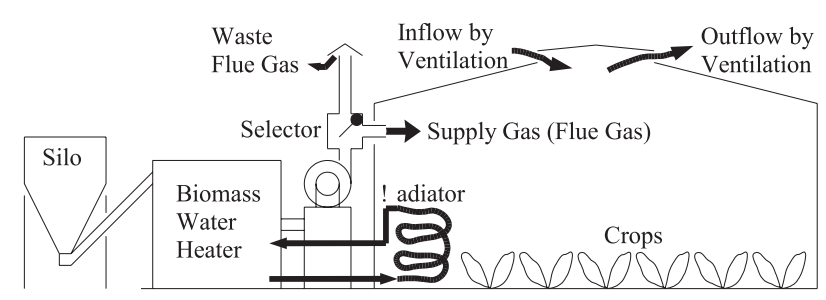

(b) Flow model of Supplied_air Duct System

Fig. 6 Flow Model of Energy Supply \& $\mathrm{CO}_{2}$ Fertilization System.

温室内空気を燃焼空気として燃焼機内に取り込んで二酸化 炭素ガスを放出する方式, 後者は温室外から二酸化炭素ガ スを送り达む方式である。化石燃料を使用する現行機器の 場合, 前者は分散型設置温風式加温, 後者は集中型設置温 湯式加温という使い分けがおこなわれている。本報でも， 同様な使い分けを設定した。

3.2.2 排ガス中の化学物質許容上限濃度

排ガス中の化学物質許容上限濃度は次式で表すことがで きる ${ }^{8)}$ 。 
高 温 学 会 誌 第 33 巻 第 1 号 $(2007$ 年 1 月)

Table 3 Maximum permissible concentration of chemical substances for crops and humans.

\begin{tabular}{|c|c|c|c|c|c|c|c|}
\hline \multirow[t]{2}{*}{ Chemical substances } & \multicolumn{3}{|c|}{$\begin{array}{l}\text { Crop damage thresholds } \\
{[\mathrm{ppm}]}\end{array}$} & \multicolumn{3}{|c|}{$\begin{array}{l}\text { Occupational exposure limits } \\
\text { (OELs) [ppm] }\end{array}$} & \multirow{2}{*}{$\begin{array}{l}\text { Environmental } \\
\text { quality standards } \\
\text { for air [ppm] }\end{array}$} \\
\hline & PBG & $\mathrm{Y}$ & $\mathrm{Z}$ & $\mathrm{JSOH}$ & $\mathrm{Y}$ & $\mathrm{X}$ & \\
\hline Ammonia $\left(\mathrm{NH}_{3}\right)$ & $0.197 !$ & N/A & 10 & $25(17)$ & N/A & 50 & N/A \\
\hline Carbon monoxide(CO) & $2.4 \vdots$ & $100:$ & 500 & $50(57)$ & $50 !$ & 100 & 1 \\
\hline Carbon dioxide $\left(\mathrm{CO}_{2}\right)$ & 2,000 & 2,000 & N/A & $5,000(9,000)$ & $5,000 \vdots$ & N/A & N/A \\
\hline Ethylene $\left(\mathrm{C}_{2} \mathrm{H}_{4}\right)$ & $0.008:$ & $0.1:$ & 0.05 & N/A & N/A & N/A & N/A \\
\hline Formaldehyde(HCHO) & N/A & $0.1:$ & 0.7 & $0.5(0.61)$ & $2 \vdots$ & 5 & N/A \\
\hline Nitrogen monoxide(NO) & 0.25 & 20 & N/A & N/A & $25 \vdots$ & $\mathrm{N} / \mathrm{A}$ & N/A \\
\hline Nitrogen dioxide $\left(\mathrm{NO}_{2}\right)$ & $0.132 !$ & $5:$ & 20 & Pending & $5 \vdots$ & 5 & $0.04 \sim 0.0$ \\
\hline Ozone $\left(\mathrm{O}_{3}\right)$ & $0.028:$ & $0.1:$ & 0.2 & $0.1(0.20)$ & $0.1 !$ & 0.1 & N/A \\
\hline Sulfur dioxide $\left(\mathrm{SO}_{2}\right)$ & $0.015 \vdots$ & $0.3:$ & 0.2 & Pending & $5 !$ & 5 & 0.04 \\
\hline
\end{tabular}

PBG: The Proefstation voor Bloemisterij en Glasgroente (1997)

Y: Vegetables Research Institute in Japan (1977)

X: Thomas, M. D. (1961)

Z: Berkel, N. van (1968)

JSOH: The Japan Society for Occupational Health (2004), Parenthesis: [mg m ${ }^{-3}$ ]

Environmental Quality Standards for Air: Air Pollution Control Law: Ministry of the Environment (1996)

Table 4 Example of emission data of heaters.

\begin{tabular}{|l|c|c|r|r|r|}
\hline $\begin{array}{c}\text { Fuel } \\
\text { Moisture) }\end{array}$ & $\begin{array}{c}\text { Published } \\
\text { Source }\end{array}$ & $\begin{array}{c}\text { Heater's } \\
\text { Maker }\end{array}$ & $\begin{array}{c}\text { Output } \\
{[\mathrm{kW}]}\end{array}$ & $\begin{array}{c}\text { CO } \\
{[\mathrm{ppm}]}\end{array}$ & $\begin{array}{c}\text { NOx } \\
{[\mathrm{ppm}]}\end{array}$ \\
\hline LPG & N Co. & N Co. & 1,160 & 1 & N/A \\
\hline Chip & K Pref. & S Co. & 110 & 700 & N/A \\
\hline Chip (100) & I Pref. & O Co. & 100 & 200 & N/A \\
\hline Chip (61) & I Pref. & S Co. & 240 & N/A & 84 \\
\hline Chip (61) & I Pref. & S Co. & 450 & N/A & 69 \\
\hline Chip (30) & K Co. & K Co. & 290 & N/A & 63 \\
\hline Pellet & I Pref. & SP Co. & 50 & 150 & 70 \\
\hline Pellet & K Co. & K Co. & 296 & 6 & 106 \\
\hline
\end{tabular}

$\left(\mathrm{C}_{\text {comp }}\right)_{\mathrm{sg}, \mathrm{u}-\text { limit }}=\mathrm{f}\left[\left(\mathrm{C}_{\text {comp }}\right)_{\mathrm{gh}, \mathrm{u}-\text { limit }}-\left(\mathrm{C}_{\text {comp }}\right)_{\mathrm{os}}\right]+\alpha\left(\mathrm{C}_{\text {comp }}\right)_{\mathrm{gh}, \mathrm{u}-\text { limit }}$ $\cdots($ 式 1$)$

ここで, $\left(\mathrm{C}_{\text {comp }}\right)_{\mathrm{sg}, \mathrm{u} \text { - limit }}$ : 排ガス中の化学物質許容上限濃度 [ppm], $\left(\mathrm{C}_{\mathrm{comp}}\right)_{\mathrm{gh}, \mathrm{u}-\mathrm{limit}}$ : 作物や作業者に対する化学物質許容 上限濃度 $[\mathrm{ppm}],\left(\mathrm{C}_{\mathrm{comp}}\right)_{\mathrm{os}}$ : 外気の化学物質濃度 $[\mathrm{ppm}], \mathrm{f}$ ： 換気流入外気と排ガスの流量比, $\alpha$ : 排ガスの供給方式に 依存する係数（送風ダクト方式: 1 , 室内発生方式: $1-\mathrm{B}^{-1}$ ), B : 排ガスの対燃焼空気流量比である。

式 1 より, 送風ダクト方式か室内発生方式, あるいは $\mathrm{f}$ や Bによって排ガス中の化学物質許容上限濃度が大きく変 化することがわかる。ここでは簡単のために, $\left(\mathrm{C}_{\text {comp }}\right)_{\text {gh, u-limit }}$ を実現すべき基準として考える。 $\left(\mathrm{C}_{\mathrm{comp}}\right)_{\mathrm{gh}, \mathrm{u}-\mathrm{limit}}$ は報告によっ てかなりの差がある。本報の目的からも, より厳しい上限 濃度以下に抑える必要があるが, 同時に技術的限界も存在 することがわかっている。Table 3 に抜粋を示した。
Table 4 に，プロパンガスを燃料とする現行機器の排ガ ス性状の例と, 給湯暖房用にここ最近設置の拡大が進んで きた木質バイオマス給湯暖房機のそれを示した。

二酸化炭素ガス施肥は，現在灯油や燃料ガスを燃焼する 機器が広く使用されている。これらは, 小型から大型に至 るまで着火消火時を除いて定常燃焼中の排ガス中の一酸化 炭素ガス濃度が測定器の検出限界程度になるように設計製 造されている。しかし, 窒素酸化物は許容上限濃度を下回 ることができず，硫黄酸化物は燃料中の含有量に左右され ることが見出されている ${ }^{8)}$ 。

木質バイオマスを燃料とした場合，短時間の暴露でも人 体にとって極めて重大な影響を及ぼす一酸化炭素ガス濃度 が許容上限濃度を大きく上回るため, 現状のままでは適用 することができないと判った。

\subsection{3 排ガス中の然焼灰}

木質バイオマスには灰分が多く含まれるため, A 重油等 と異なり燃焼灰の扱いを考慮する必要がある。木質バイオ マス燃焼機からの燃焼ガスに随伴して運ばれる燃焼灰（以 下，飛灰）の集塵機における回収は次式で表すことができ る。

$$
\mathrm{W}_{\mathrm{a}}=\mathrm{W}_{\mathrm{s}}\left(\eta_{\mathrm{s}}^{-1}-1\right)
$$

ここで, $\mathrm{W}_{\mathrm{a}}$ : 飛灰未回収量 $\left[\mathrm{kg} \mathrm{h}^{-1}\right], \mathrm{W}_{\mathrm{s}}$ : 集塵機の飛灰 回収量 $\left[\mathrm{kg} \mathrm{h}^{-1}\right], \eta_{\mathrm{s}}$ : 集塵機の飛灰回収効率である。

燃焼機内部で生成した燃焼灰は本体灰溜部で回収され (以下, 主灰), 飛灰は集塵機扊溜部で回収され, そして最 終的に回収できなかった飛灰がばいじんとして煙突から放 出される。主灰と回収飛灰の割合は燃焼機の構造に大きく 
依存し, 回収飛灰と未回収飛灰の割合は集塵機の構造・性 能に大きく依存する。

定格熱出力 $116 \mathrm{~kW}$ 級の木質バイオマス燃焼機で Table 1 のホワイトペレット（灰分 $0.28 \%$ ） を燃焼すると, 約 $73 \mathrm{~g}$ $\mathrm{h}^{-1}$ の燃焼灰が発生する。シングルサイクロン式集塵機の 飛灰回収効率 $\eta_{\mathrm{s}}=0.9$ とすると, 最大 $7.3 \mathrm{~g} \mathrm{~h}^{-1}$ のばいじん が煙突から放出される。このときの排ガス量を $600 \mathrm{~m}^{3} \mathrm{~h}^{-}$ 1 とすると, ばいじん濃度は $12 \mathrm{mg} \mathrm{m}^{-3}$ となる。この值は, 大気污染防止法に定められるばい煙発生施設の許容上限濃 度 $300 \mathrm{mg} \mathrm{m}^{-3}$ は下回るが, 産業衛生学会の許容濃度勧告 值 $0.5 \sim 2 \mathrm{mg} \mathrm{m}^{-3}$ や大気污染環境基準 $0.1 \mathrm{mg} \mathrm{m}^{-3}$ を大き く上回る。ここで, 通常一般的に使用されている経済的な シングルサイクロン式集塵機を高価なマルチサイクロン式 $\left(\eta_{\mathrm{s}}=0.95\right)$ にすると, ばいじんの量は半分程度に減少す るが, それでも勧告值以下にならないことも判る。木質バ イオマスの直接燃焼において, 予め燃料から灰分だけを取 り除くことは現実的ではないため, 上述の基準值内に抑え る必要があるときには, 更に高価な電気集塵機等を使用す るしかなく，温室向けとしては現実的ではない。

更に, ばいじんが温室被覆材に付着して日射を弱める恐 れがある。

一方, 回収できた燃焼灰は, 化学的組成や物理的形状に よるが肥料としての利用が見込まれている。しかし, 農地 への肥料としての利用を考える場合, 作物への影響（施肥 時期, 施肥量, 塩類集積, 生育障害), 作業者への影響 (呼吸, 手あれ), そして環境への影響（河川, 地下水, 周辺への飛散） を充分に考慮する必要がある。日々大量に回収される燃焼 灰の処理を予め決定しておく必要があるが, このような確 認がなされていないうちは性急な農地への適用は控えるべ きである。

結果的に，農家の大きな負担となることが，導入を妨げ ている原因となっている。

\section{4. 結 論}

温室に対するエネルギー・二酸化炭素ガス施肥源として 再生可能エネルギー・資源である木質バイオマスを適用す る場合の下記留意点を得た。

1) 温室への二酸化炭素ガス施肥基準から二酸化炭素ガス施 肥に適用するのは困難であるため, 当面はエネルギー利 用だけに留めるべきである。

2) 経済性, 高信頼性, そして保守容易性を満たす, 温室向 けの実用的なバイオマスエネルギー機器が必要である。
3) 環境制御要求がシビアでない作物品種や栽培システムの 開発が必要である。

4) 多量に発生する燃焼灰の処理，有効活用が必要である。

\section{引用文献}

1）島地 英夫：“複合環境制御と省エネルギー技術”，五訂・施設 園芸ハンドブック, 日本施設園芸協会編, 園芸情報センター, (2003) 206-216

2) 野口 正樹：“作型と栽培管理 (1) 野菜”, 五訂・施設園芸ハン ドブック，日本施設園芸協会編，園芸情報センター，（2003） 376-393

3) 大須賀 隆司: “二酸化炭素制御”，五訂·施設園芸ハンドブック， 日本施設園芸協会編，園芸情報センター，（2003）376-393

4) http://www.biomass-hq.jp/biomasstown/index.html

5) バイオマスエネルギー導入ガイドブック検討委員会: “バイオ マスエネルギー導入ガイドブック（第 2 版 a)”, NEDO, (2005) 28-32

6) 川村淳浩, 秋澤 淳, 柏木 孝夫, 原田秀一, 渡邊直紀 : “農 作物生産用温室へのコージェネレーションシステム適用性評 価”，日本エネルギー学会誌，85(5)（2006）390-397

7) 川村淳浩, 秋澤 淳, 柏木 孝夫, 原田秀一, 渡邊 直紀 : “農 作物生産用温室へのコージェネレーションシステム適用指針 構築に関する研究 (第 2 報)”, 第 25 回エネルギー・資源学会 研究発表会講演論文集, (2006）239-242

8）川村 淳浩：“数式モデルを用いた温室における各種燃焼式二 酸化炭素供給法の得失評価”, 植物工場学会誌, 16-2（2004） 10-22

9）遠竹行俊, 村田仁, 桶川秀実：“木質源バイオマスの利用開 発試験 (1) 木質バイオマスエネルギー資源開発”, 平成 13 年 度東京都林業試験場年報, (2001)

10）遠竹行俊, 中川清子, 新井一司, 村田仁, : “木質源バイ オマスの利用開発試験 (1) 木質バイオマスエネルギー資源開 発”，平成 14 年度東京都林業試験場年報, (2002)

11) 園田 哲也, 田中 憤造, 堀田昌宏, 飯村 崇: “木質バイオマス ストーブの開発”, 岩手県工業技術センター研究報告, 9 (2002)

12）園田哲也, 堀田昌宏, 田中愼造, 遠藤治之, 東矢恭明, 高 川貫仁, 真賀幸八, 落合昇, 北田佳晴: “いわて型ペレッ トストーブの開発”, 岩手県工業技術センター研究報告, 10 (2003)

13）林 真紀夫: “温度制御 (2) 暖房”, 五訂・施設園芸ハンドブック, 日本施設園芸協会編，園芸情報センター，（2003）127-141

14) 我孫子和雄：“病害虫・生育（連作）障害 (1) 主要病害と防 除”，五訂・施設園芸ハンドブック，日本施設園芸協会編，園 芸情報センター,（2003）419-425 